\title{
Benthic communities of common reed Phragmites australis and marsh cordgrass Spartina alterniflora marshes in Chesapeake Bay
}

\author{
Martin H. Posey ${ }^{1, *}$, Troy D. Alphin ${ }^{1}$, David L. Meyer ${ }^{2}$, John M. Johnson² \\ ${ }^{1}$ Center for Marine Science and Department of Biological Sciences, University of North Carolina Wilmington, \\ 5600 Marvin K. Moss Lane, Wilmington, North Carolina 28409, USA \\ ${ }^{2}$ National Oceanic and Atmospheric Association (NOAA), Center for Coastal Fisheries and Habitat Research, \\ 101 Pivers Island Road, Beaufort, North Carolina 28516, USA
}

\begin{abstract}
Invasive species are receiving increased attention both for their direct effects, including competitive displacement and predator-prey interactions, and indirect effects involving ecosystem and habitat alterations. The common reed Phragmites australis is spreading along much of the Atlantic and Gulf coasts of the USA. Its spread is particularly apparent in disturbed oligohaline to mesohaline areas, where it may displace the marsh cordgrass Spartina alterniflora. Because of the different morphologies of these plants, associated sediment effects, and differences in biogeochemical cycling, there is the potential for significant faunal community changes where macrophyte species replacement occurs. We conducted a study in the mesohaline region of Chesapeake Bay to examine differences between benthic communities associated with $S$. alterniflora and $P$. australis marshes. Paired $P$. australis and $S$. alterniflora marshes were sampled at 4 sites in summer and 2 sites in fall, blocking for tidal height (high marsh versus low marsh) and small-scale topographic features (rivulet and hummock areas in each marsh type). Sediment grain size did not differ between marsh types, and percent organics differed only for $P$. australis hummock sites compared to other habitat types. Benthic microalgal biomass also did not differ among marsh types. There was only a small effect on faunal abundance patterns, with most species exhibiting slightly higher mean density in Spartina compared to adjacent Phragmites marshes. Much stronger differences in faunal density were observed between hummocks and adjacent rivulets within each marsh type. While macrophyte type had a detectable effect, local microhabitat characteristics had a stronger relation to local faunal abundance patterns. Since such microhabitat characteristics may covary with macrophyte type (although they did not do so in this study), care must be taken in the design and interpretation of comparative marsh studies and more emphasis should be given to including relations of small-scale topographic features with faunal characteristics. In this system and on the scale studied here, macrophyte replacement did not strongly affect the benthic infaunal community.
\end{abstract}

KEY WORDS: Phragmites australis $\cdot$ Spartina alterniflora $\cdot$ Benthos $\cdot$ Invasive species $\cdot$ Chesapeake Bay $\cdot$ Marsh topography

\section{INTRODUCTION}

Tidal marshes are widely recognized as an important habitat for a variety of fishes and decapods (Levinton 1982). Spartina alterniflora (hereafter referred to as 'Spartina') marshes and their associated channel com- plexes support ecologically important resident species (Kneib \& Stiven 1978, Kneib 1984, 1988, McIvor \& Odum 1988, Minello \& Zimmerman 1992) as well as juveniles of transient species, including, on the east coast of the US, commercially important nekton such as spot, croaker, flatfish, penaeid shrimp, and blue 
crabs (Boesch \& Turner 1984, Zimmerman \& Minello 1984, Hettler 1989, Minello \& Zimmerman 1992, Minello et al. 1994). Nekton use tidal marsh habitats both as a critical foraging area (Miltner et al. 1995) and for refuge during times of tidal inundation (Peterson \& Turner 1994, Rozas \& Zimmerman 2000).

A recent concern for the management of oligohaline to mesohaline marshes along the Atlantic coast of the US has been the spread of the common reed Phragmites australis (hereafter referred to as 'Phragmites'). Although Phragmites has been an historic constituent of northeastern oligohaline marshes, it began to dramatically spread in the 1960s (Warren \& Fell 1995, Rice et al. 2000), possibly reflecting the introduction of a new genotype (Blossey 2002). However, the native distribution and reasons for its recent invasiveness are still uncertain. Phragmites is now expanding its range along the whole east coast of the US, especially in disturbed habitats. In many locations, Phragmites has replaced oligohaline and mesohaline marsh macrophytes, including Spartina, or produced mixed vegetation stands (Havens et al. 1997, Chambers et al. 1999, Rice et al. 2000, Weis \& Weis 2000, Talley \& Levin 2001).

Replacement of Spartina by Phragmites has led to concerns about shifts in habitat quality, since faunal patterns may vary with changes in vegetation type (LaSalle \& Bishop 1987, Posey et al. 1997, Talley \& Levin 1999). Phragmites stands present a different physical structure than Spartina, with larger but less dense stands of stems and a lower relative belowground biomass (Meyerson et al. 2000, Windham 2001). Differences in growth form and structure of these plants may be associated with differences in detrital production, potential water flow through the stems, root mass, sediment organic content and nutrient cycling (Meyerson et al. 2000, Talley \& Levin 2001, Windham 2001) as well as patterns of sediment deposition within the macrophyte stands (Weinstein \& Balletto 1999, Rooth \& Stevenson 2000, Leonard et al. 2002).

While physical and geochemical differences among Phragmites and Spartina marshes have been noted, the influence of these macrophytes on fauna is less clear, and comparisons between the 2 marsh types have provided mixed results. Some studies of marsh utilization by nekton have indicated no detectable difference among these marsh types (Fell et al. 1998, Able et al. 2001, Meyer et al. 2001), yet other studies have indicated lower abundances of certain species and of certain life stages within Phragmites compared to Spartina marshes (Weinstein \& Balletto 1999, Able \& Hagan 2000). Bird abundance and species richness were lower in a $P$. australis marsh than in an S. alterniflora marsh (Benoit \& Askins 1999). Laboratory studies have suggested some behavioral avoidance of Phragmites by juvenile fishes (Weis \& Weis 2000). Talley \&
Levin (2001) found that certain benthic fauna were less dense within northeastern Phragmites compared to Spartina marshes (specifically gastropods, midges and oligochaetes) while other taxa were more common (sabellid polychaetes in Phragmites). However, Fell et al. (1998) found no evidence for significant differences in prey-resource availability for mummichogs (mostly surface-oriented infauna and selected epifauna) among the 2 marsh types. Possible reasons for variability in macro-infaunal response may involve interactions among macrophyte type and landscape aspects, nutrient and sediment regimes, and local invertebrate species pools. In some locations, $P$. australis marshes may serve as sediment sinks, even forming mounded areas (Rooth \& Stevenson 2000). However, such effects are variable among $P$. australis marsh sites and also may occur in $S$. alterniflora-dominated marshes (Meyer et al. 2001).

Studies evaluating both functional characteristics of Phragmites (e.g. habitat provision) and comparisons of fauna among vegetation types are limited. This underscores the need for additional information on the potential effects of Phragmites replacement of Spartina on associated communities. Differences between these marsh types may depend on covariate factors interacting with structural aspects of each plant type. Among the possible reasons for variability in abundance are variations in surface topography among the vegetation types (Weinstein \& Balletto 1999) or geographic variations in background faunal availability. While studies have independently examined aspects of topography within a marsh type (usually Spartina) or have compared fauna among marsh types, few studies have examined the relative effects of plant type, topography and location in combination.

We compared the benthic macrofaunal communities from adjacent Phragmites and Spartina marshes at 4 sites in the mesohaline region of Chesapeake Bay, controlling for topographic variability among the vegetation types through stratified sampling in both rivulet and hummock areas and at 2 marsh elevations for each site. The general study area is a good location for the study of Phragmites effects because of the close occurrence of monospecific stands of both Phragmites and Spartina (allowing a paired-site sampling design) as well as the presence of rivulet and hummock features in both marsh types (allowing observation of topographic effects independent of the dominant macrophyte species).

\section{MATERIALS AND METHODS}

Study sites. The study was conducted within the Chester River and Prospect Bay regions of Chesa- 
peake Bay, an area of mesohaline to oligohaline salinities (Meyer et al. 2001; present Fig. 1). Within this region we sampled 4 sites with paired Phragmites and Spartina marshes: (1) Muddy Creek (MUD), (2) Marshy Creek North (MCN), (3) Marshy Creek East (MCE), and (4) Marshy Creek South (MCS). The paired marshes within a site were 100 to $400 \mathrm{~m}$ distant from each other, and each site was 1 to $2 \mathrm{~km}$ from the next nearest site. Sampling within a marsh was conducted within an area that was $10 \mathrm{~m}$ across and extended $6 \mathrm{~m}$ from the water's edge into the marsh interior. This area contained numerous vegetated hummocks interspersed by small ( 20 to $30 \mathrm{~cm}$ wide) sinuous rivulets. Hummocks are raised, vegetated areas 5 to $10 \mathrm{~cm}$ higher than adjacent rivulets and separated by the unvegetated rivulets (small drainage channels). All areas drained at low tide. Percent rivulet versus hummock varied among sites, but was similar for different plant (marsh) types within a site (Fig. 2). Paired marshes were located in the same creek and were chosen to have similar tidal elevations, creek order, salinity and hydroperiod (Meyer et al. 2001). Spartina marshes had Distichis spicata as a subdominant in the upper marsh, while Phragmites marshes were $>90 \%$ dominated by this 1 macrophyte species (measured by stem density; Meyer et al. 2001). Sampling within a marsh was stratified by topography (rivulet versus hummock) and marsh elevation (high marsh and low marsh - an average elevation difference of $20 \mathrm{~cm}$, with high-marsh areas located 4 to $6 \mathrm{~m}$ horizontally into the marsh and low marsh areas located within the first $2 \mathrm{~m}$ ). There were 4 subsites within a marsh, representing full combinations of the 2 elevations and 2 topography types.

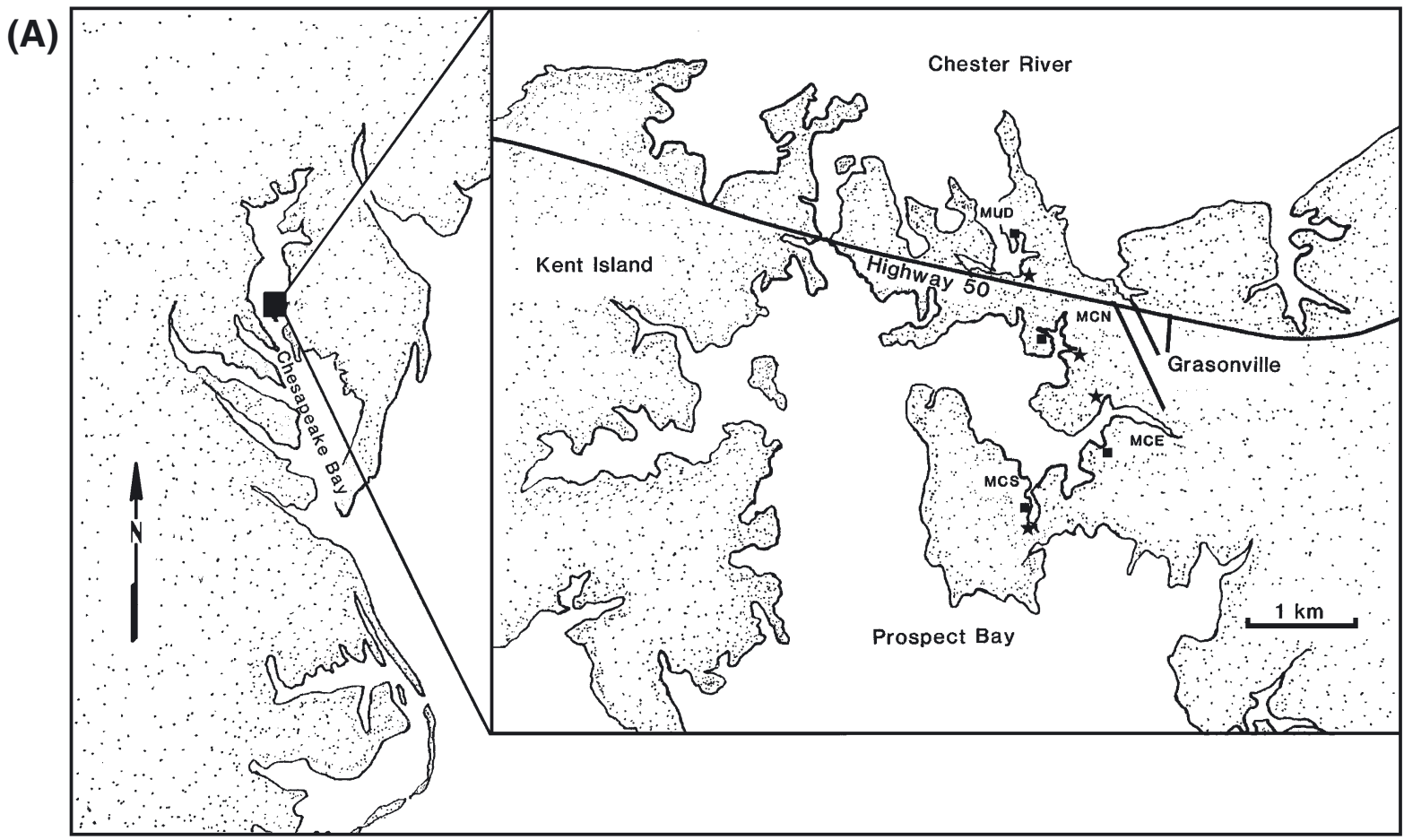

(B)

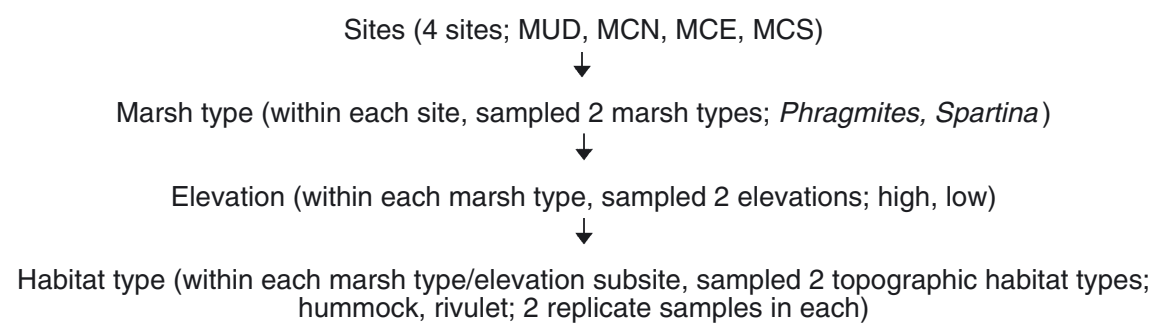

Fig. 1. (A) Location of study sites in central Chesapeake Bay. MUD: Muddy Creek, MCN: Marshy Creek North; MCE: Marshy Creek East; MCS: Marshy Creek South; subsites representing Phragmites australis marsh (*) and Spartina alterniflora marsh $(\bullet)$ are identified within each site. (B) Summary of variables examined indicating stratification of main factors 

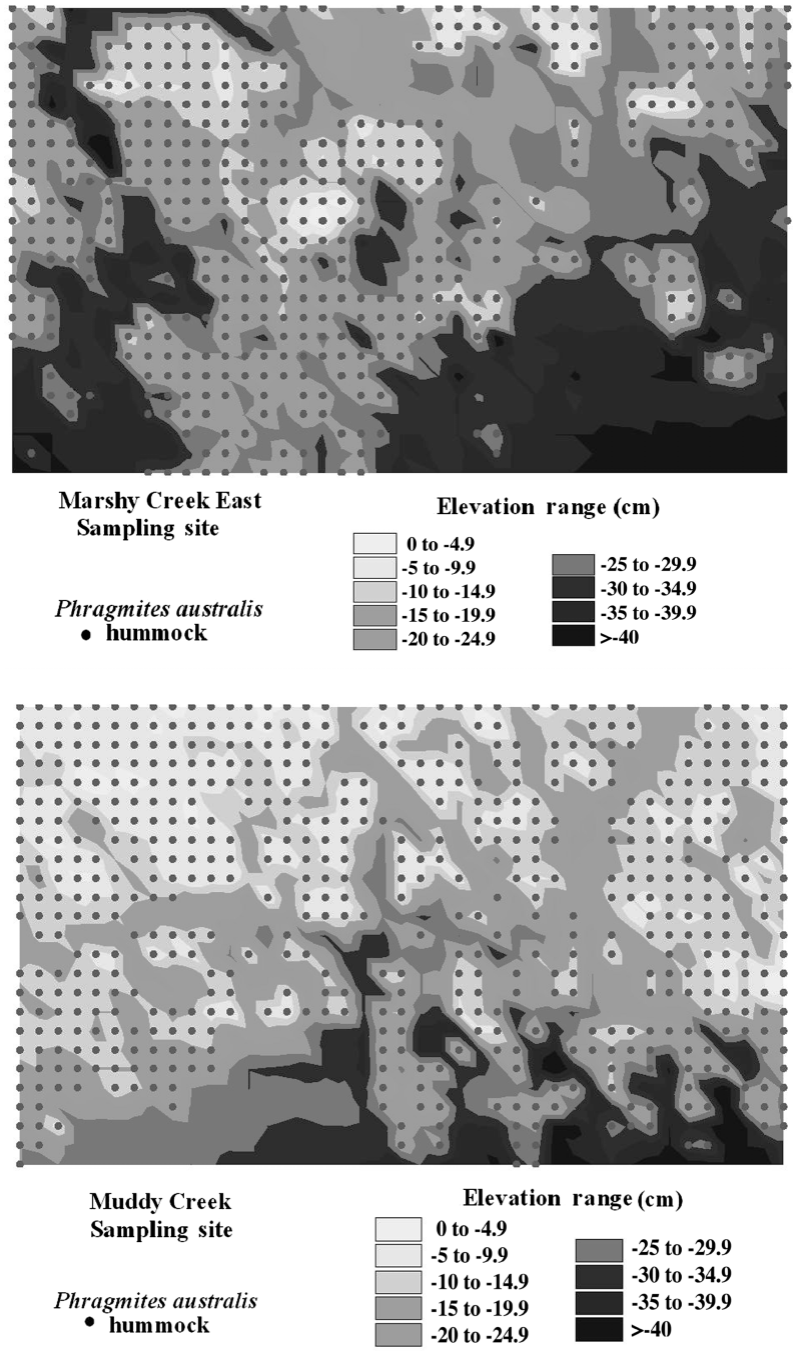
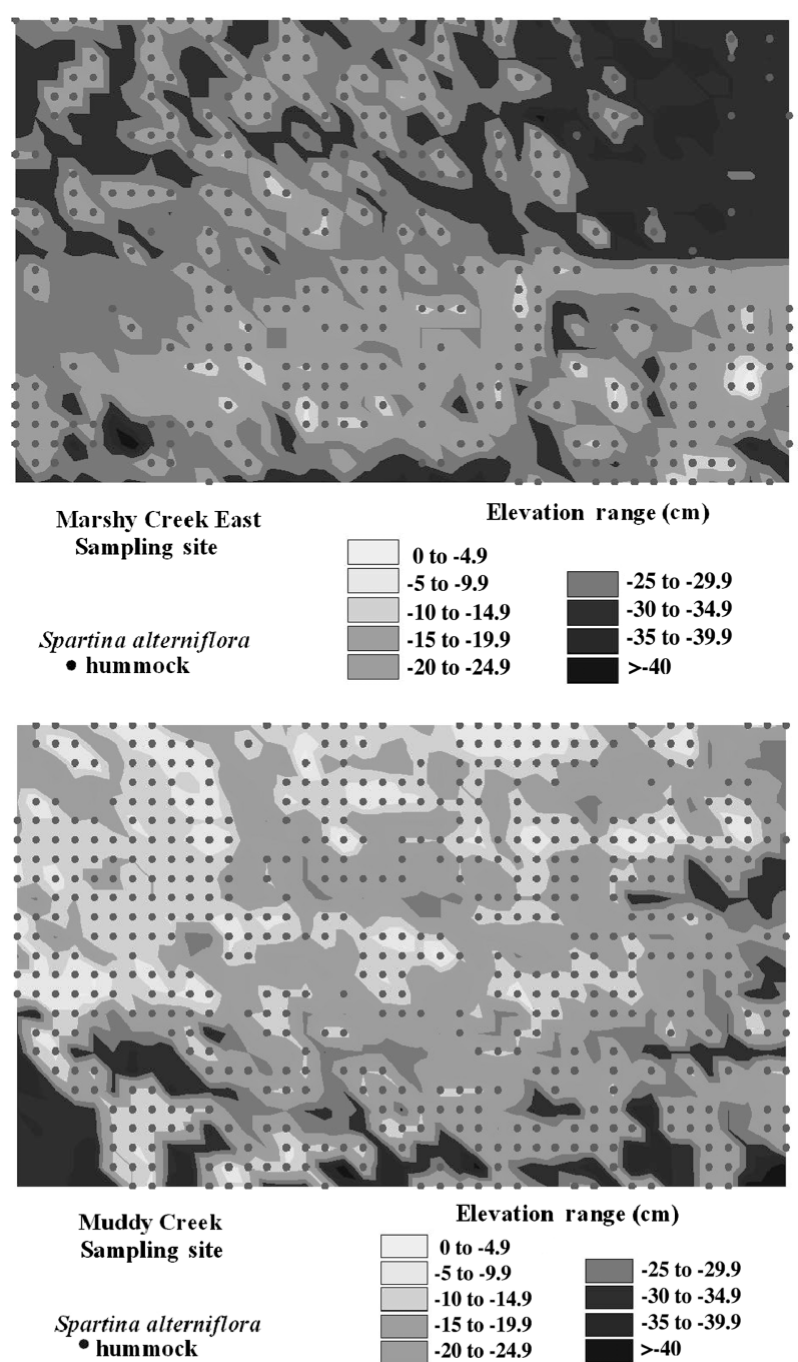

Elevation range $(\mathrm{cm})$

0 to -4.9

0 to -4.9
-5 to -9.9

-5 to -9.9
-10 to -14.9

-15 to -19.9

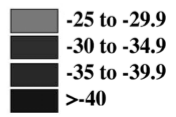

Fig. 2. Phragmites australis and Spartina alterniflora marshes. Relative elevation and rivulet/hummock patterns at 2 representative sites (MCE and MUD). Note that relative cover of hummock areas and elevation patterns are more similar for different macrophyte types within a site than for the same macrophyte types between sites

\section{Methodology. Organics and sediment composition:}

Cores for percent organics and sediment grain-size composition were taken at paired rivulet/hummock areas within high- and low-marsh locations in each paired marsh type at a site (paired Phragmites and Spartina marshes at each of 4 sites) during summer 1998. The samples were placed immediately on ice and subsequently frozen. Sediment samples were analyzed for percent silt/clay and organic content for each of the treatments across all the sites according to the methods described by Royce (1970).

Size fractions for the sediment were determined by washing a $5 \mathrm{~g}$ subsample of sediment through a standard sieve series. Each sediment fraction was dried for $24 \mathrm{~h}$ at $100^{\circ} \mathrm{C}$ and percent composition determined by relative dry weight. Percent silt/clay was determined using the filtrate obtained from wet-sieving. This filtrate was placed in a graduated cylinder, $20 \mathrm{ml}$ of sodium hexametaphosphate was added to prevent flocculation, and the remaining volume of the $1000 \mathrm{ml}$ cylinder was filled with deionized water and homogenized. After $24 \mathrm{~h}$ the sample was rehomogenized, and after $20 \mathrm{~s}$ three $40 \mathrm{ml}$ subsamples were taken. These subsamples were dried for $24 \mathrm{~h}$ at $100^{\circ} \mathrm{C}$, and the percent silt/clay was determined relative to the total sample dry weight.

For percent organics, a preweighed subsample of sediment was dried at $100^{\circ} \mathrm{C}$ for $24 \mathrm{~h}$; the sample was then ground into a fine powder using a mortar and pestle and combusted at $500^{\circ} \mathrm{C}$ for $24 \mathrm{~h}$. Percent or- 
ganics was determined as a ratio of weight loss after combustion to dry weight before combustion.

Benthic chlorophyll a: Benthic chlorophyll a for each site was collected in April 1998 and concurrent with infaunal collections in July/October 1998 (see next subsection). We collected 3 surface sediment cores, measuring $1.1 \mathrm{~cm}$ diameter $\times 1.0 \mathrm{~cm}$ deep for each elevation (high marsh 3 to $6 \mathrm{~m}$ from the front fringe, low marsh 0 to $2 \mathrm{~m}$ from the front fringe) and microhabitat type (rivulet and hummock) from each paired vegetation type at a site. The total number of samples taken within each paired vegetation type at a site was 12 . Benthic chlorophyll $a$ and pheopigments were determined spectrophotometrically based on methods employed by Pinckney \& Zingmark (1993). A 45:45:10 acetone: methanol:distilled water mixture was added to samples and sonicated to liberate and extract pigments. After $24 \mathrm{~h}$ extractions, the samples were centrifuged and the solvent was extracted for spectrophotometric analyses. The Lorenzen equations (Lorenzen 1967) were used to calculate chlorophyll $a$ and pheopigment content.

Percent (proportion) silt content, percent organics and chlorophyll a concentration were compared among macrophyte type, topographic features and tidal levels blocking for marsh locations using analysis of variance (ANOVA) with 2- and 3-way interactions. Because proportions were all less than 0.05 and data for both sediment characteristics and chlorophyll $a$ concentrations were normally distributed with nonheterogeneous variance, no transformation was necessary. Where interactions occurred (the only interaction was a weak plant type $\times$ topography interaction for $\%$ organics), effects were examined separately by macrophyte type and topographic characteristics.
Macro-infaunal community patterns: Macro-infauna was sampled using $0.007 \mathrm{~m}^{2} \times 12 \mathrm{~cm}$ deep cores taken at low tide. As with sediment and chlorophyll a samples, cores were taken at paired rivulet/hummock areas within high- and low-marsh locations in each marsh type (paired Phragmites and Spartina marshes at each of 2 to 4 sites). All 4 sites were sampled in July 1998, while 2 sites (MUD and MCN) were sampled in October 1998. At each sampling location, 2 cores were taken (between stems for hummock areas), but these were combined for later statistical analyses because of possible nonindependence at that spatial scale. Cores were preserved in $10 \%$ formalin solution with added rose bengal dye. Cores were left in formalin for at least $1 \mathrm{wk}$; the contents were then sieved through a $0.5 \mathrm{~mm}$ screen, and the residue was transferred to $50 \%$ isopropanol for storage until identification. Animals were removed from the root matrix under a dissecting microscope.

ANOVA was used to compare abundances of common fauna (individual taxa representing at least $1 \%$ of the total individuals sampled during either summer or fall) using a Type III Model ANOVA (Sokal \& Rohlf 1981) including the main effects of macrophyte type (Phragmites vs Spartina; F1 variable: SAS Institute 1990), topography (rivulet vs hummock), elevation (high vs low marsh), and site, as well as 2-way and 3way interactive effects among these variables. Analyses were conducted separately for summer and fall samples because of seasonal differences in faunal composition and fewer sites sampled in the fall. Data were log-transformed before analysis to meet assumptions of non-heterogeneity of variances and normality ( $F_{\text {max }}$ test; Sokal \& Rohlf 1981). Significant interactions were only detected among 7 comparisons (Tables 1 \& 2)

Table 1. Phragmites australis and Spartina alterniflora marshes. Main and interactive effects of plant type, topography, topo (rivulet vs hummock), elevation, elev (high vs low marsh) and site (MUD, MCN, MCE, MCS) for dominant macrofaunal species (those taxa comprising at least $1 \%$ of individuals) during summer samples. Shown are $F$-values with significance levels in parentheses (significant relations are indicated by bold type). All interactions not shown were non-significant for all taxa. Error: $\mathrm{df}=17$. See Fig. 1 legend for explanation of site acronyms

\begin{tabular}{|c|c|c|c|c|c|c|c|c|}
\hline Taxon & $\begin{array}{l}\text { Plant type } \\
\text { (1 df) }\end{array}$ & $\begin{array}{l}\text { Topography } \\
\text { (1 df) }\end{array}$ & $\begin{array}{l}\text { Elevation } \\
\quad(1 \mathrm{df})\end{array}$ & $\begin{array}{l}\text { Site } \\
\text { (3 df) }\end{array}$ & $\begin{array}{c}\text { Plant } \times \text { topo } \\
(1 \mathrm{df})\end{array}$ & $\begin{array}{l}\text { Plant } \times \text { elev } \\
\quad(1 \mathrm{df})\end{array}$ & $\begin{array}{c}\text { Topo } \times \text { elev } \\
(1 \mathrm{df})\end{array}$ & $\begin{array}{c}\text { Plant } \times \text { site } \\
(3 \mathrm{df})\end{array}$ \\
\hline Capitella capitata & $2.80(0.11)$ & $0.20(0.66)$ & $0.01(0.93)$ & $0.94(0.44)$ & $0.01(0.99)$ & $0.26(0.62)$ & $1.01(0.33)$ & $0.88(0.47)$ \\
\hline Chirodotea & $0.56(0.47)$ & $4.51(0.049)$ & $5.34(0.034)$ & $12.54(0.0001)$ & $0.10(0.75)$ & $1.18(0.29)$ & $0.14(0.72)$ & $1.13(0.37)$ \\
\hline Chironomus spp. & $1.04(0.32)$ & $0.95(0.34)$ & $0.03(0.86)$ & $0.76(0.53)$ & $0.91(0.35)$ & $0.20(0.66)$ & $1.34(0.26)$ & $0.26(0.86)$ \\
\hline Cyrenoidea & $1.21(0.29)$ & $1.17(0.20)$ & $1.75(0.20)$ & $9.64(0.0006)$ & $1.06(0.32)$ & $<0.01(0.998)$ & $0.66(0.43)$ & $0.91(0.45)$ \\
\hline Diptera & $0.05(0.8$ & $1.79(0.20)$ & $0.29(0.60)$ & $0.15(0.93)$ & $2.10(0.17)$ & $0.41(0.53)$ & $2.86(0.11)$ & $0.09(0.96)$ \\
\hline $\begin{array}{l}\text { Gammarus } \\
\text { mucronatus }\end{array}$ & $4.18(0.05)$ & $12.81(0.002)$ & $1.87(0.19)$ & $2.05(0.15)$ & $8.36(0.01)$ & $0.87(0.36)$ & $0.24(0.63)$ & $0.15(0.93)$ \\
\hline Hobsonia florida & $1.57(0.23)$ & $9.95(0.006)$ & $0.40(0.54)$ & $2.06(0.14)$ & $2.19(0.16)$ & 0.24( & $0.29(0.60)$ & 0.17 \\
\hline Hydrobia minuta & $17.53(0.0006)$ & $24.91(0.0001)$ & $1.08(0.31)$ & $1.11(0.37)$ & $20.31(0.0003)$ & 3) $0.53(0.48)$ & $4.59(0.047)$ & 3.88 \\
\hline Laeonereis culveri & $3.50(0.079)$ & $11.24(0$ & $1.76(0.20)$ & $4.72(0.014)$ & & & $0.049)$ & 0.48 \\
\hline Leptochelia dubia & & 23.1 & & & & & & \\
\hline & & & & & & 0.01 & 0.01 & 0.11 \\
\hline Oligochaeta & $0.01(0.91)$ & $3.55(0.077)$ & $0.98(0.34)$ & $0.09(0.96)$ & $0.89(0.36)$ & $0.35(0.56)$ & $0.45(0.51)$ & $0.36(0.79)$ \\
\hline Total fauna & $4.02(0.061)$ & $1.52(0.23)$ & $<0.01(0.95)$ & $0.18(0.91)$ & $0.47(0.50)$ & $0.39(0.54)$ & $2.02(0.17)$ & $1.79(0.19)$ \\
\hline
\end{tabular}


Table 2. Phragmites australis and Spartina alterniflora marshes. Main and interactive effects of plant type, topography, topo (rivulet vs hummock), elevation, elev (high vs low marsh) and site (MUD, MCN) for dominant macrofaunal species (those taxa comprising at least $1 \%$ of individuals) during fall samples. Shown are $F$-values with significance levels in parentheses (significant relations indicated by bold type). All interactions not shown were non-significant for all taxa. Error: df $=6$. See Fig.1 legend for explanation of site acronyms

\begin{tabular}{|c|c|c|c|c|c|c|c|c|}
\hline Taxon & $\begin{array}{l}\text { Plant type } \\
\text { (1 df) }\end{array}$ & $\begin{array}{l}\text { Topography } \\
\text { (1 df) }\end{array}$ & $\begin{array}{l}\text { Elevation } \\
\quad(1 \mathrm{df})\end{array}$ & $\begin{array}{l}\text { Site } \\
(1 \mathrm{df})\end{array}$ & $\begin{array}{c}\text { Plant } \times \text { topo } \\
(1 \mathrm{df})\end{array}$ & $\begin{array}{c}\text { Plant } \times \text { elev } \\
(1 \mathrm{df})\end{array}$ & $\begin{array}{c}\text { Topo } \times \text { elev } \\
(1 \mathrm{df})\end{array}$ & $\begin{array}{c}\text { Plant } \times \text { site } \\
\quad(1 \mathrm{df})\end{array}$ \\
\hline Capitella capitata & $3.57(0.11)$ & $0.53(0.49)$ & $0.12(0.75)$ & $8.44(0.03)$ & $0.29(0.61)$ & $0.73(0.43)$ & $0.90(0.38)$ & $0.20(0.67)$ \\
\hline Chirodotea & $0.30(0.60)$ & $30.30(0.0015)$ & $6.74(0.041)$ & $0.04(0.84)$ & $0.21(0.66)$ & $0.51(0.50)$ & $0.06(0.82)$ & $7.03(0.04)$ \\
\hline Chironomus spp. & $0.05(0.84)$ & $3.44(0.11)$ & $0.04(0.85)$ & $0.27(0.62)$ & $0.09(0.78)$ & $0.53(0.49)$ & $0.56(0.48)$ & $3.23(0.12)$ \\
\hline Cyrenoidea & $2.23(0.19)$ & $22.56(0.003)$ & $0.06(0.82)$ & $0.49(0.51)$ & $3.06(0.13)$ & $0.01(0.93)$ & $2.29(0.18)$ & $1.84(0.22)$ \\
\hline Diptera & $0.52(0.50)$ & $8.99(0.024)$ & $0.35(0.57)$ & $0.05(0.83)$ & $0.12(0.74)$ & $0.99(0.36)$ & $0.90(0.38)$ & $1.20(0.31)$ \\
\hline $\begin{array}{l}\text { Gammarus } \\
\text { mucronatus }\end{array}$ & $1.38(0.28)$ & $19.35(0.0046)$ & $1.52(0.26)$ & $0.24(0.64)$ & $0.13(0.73)$ & $0.56(0.48)$ & $0.18(0.69)$ & $1.36(0.29)$ \\
\hline Hobsonia florida & $0.26(0.63)$ & $5.05(0.066)$ & $1.41(0.28)$ & $1.28(0.30)$ & $0.67(0.45)$ & $0.24(0.65)$ & $<0.01(0.98)$ & $0.01(0.93)$ \\
\hline Hydrobia minuta & $8.12(0.029)$ & $25.31(0.0024)$ & $0.88(0.39)$ & $0.05(0.84)$ & $0.50(0.51)$ & $2.46(0.17)$ & $0.57(0.48)$ & $2.44(0.17)$ \\
\hline Laeonereis culveri & $0.01(0.93)$ & $0.18(0.68)$ & $2.02(0.21)$ & $2.75(0.15)$ & $1.40(0.28)$ & $0.08(0.78)$ & $0.11(0.75)$ & $1.01(0.35)$ \\
\hline Leptochelia dubia & $1.83(0.23)$ & $7.43(0.034)$ & $0.48(0.51)$ & $0.58(0.47)$ & $0.03(0.88)$ & $1.14(0.33)$ & $<0.01(0.98)$ & $0.08(0.79)$ \\
\hline Acarina & $0.10(0.77)$ & $25.64(0.0023)$ & $4.75(0.072)$ & $1.14(0.33)$ & $0.94(0.37)$ & $<0.01(0.95)$ & $8.57(0.026)$ & $2.85(0.14)$ \\
\hline Oligochaeta & $0.02(0.89)$ & $0.36(0.57)$ & $0.07(0.80)$ & $2.76(0.15)$ & $0.08(0.79)$ & $0.38(0.56)$ & $0.95(0.37)$ & $0.19(0.67)$ \\
\hline Total fauna & $<0.01(0.99)$ & $1.47(0.27)$ & $1.34(0.29)$ & $0.55(0.49)$ & $0.01(0.93)$ & $<0.01(0.99)$ & $0.15(0.71)$ & $0.22(0.66)$ \\
\hline
\end{tabular}

and 6 of these were small relative to main effects $(\mathrm{p}>$ 0.025). Where interactions were strong relative to main effects (this occurred only for Hydrobia minuta in summer, involving a plant type $\times$ topography 2 -way interaction), effects were examined separately by plant type and by topographic characterization. Where main effects were detected, a Student-Newman-Keuls (SNK) post hoc test was used to distinguish effects. Because high variability in faunal abundances may obscure subtle patterns in faunal distribution, Friedman's test (Posey \& Ambrose 1984, Holland et al 1987) was used to examine general trends in rank abundance of fauna among macrophyte types or topographic regimes. This test examines the hypothesis that, on a whole-community scale, the species in the site will consistently have higher rank abundance in one macrophyte type or under a certain topographic regime. Friedman's test was conducted separately for each season. Principal components analysis (PCA) was used to determine if samples were grouped by macrophyte type, topographic regime, elevation or site. PCA was conducted using the SAS statistical package (SAS Institute 1990), and a biplot was constructed from the first 2 eigenvectors (De'ath 1999). Wards minimum cluster analysis was used to detect significant groupings of samples (De'ath 1999, Posey et al. 2002).

\section{RESULTS}

\section{Sediment and chlorophyll a characteristics}

As reflected by percent silt and clay composition (Fig. 3), sediment grain size did not differ among vari- ous macrophyte types, topographic features, or marsh elevation. All sediments were dominated by fine sands. However, percent organics was affected significantly by topography $(F=6.02, \mathrm{p}<0.023)$ and an interactive effect between topography and macrophyte type $(F=5.68, \mathrm{p}<0.027)$. Percent organics was greater in Phragmites hummock subsites compared to Phragmites rivulet or Spartina subsites (rivulet or hummock). Phragmites and Spartina rivulet subsites did not differ significantly in percent organics nor did Spartina rivulet and hummock subsites (Fig. 3). A significant site $\times$ macrophyte interaction $(F=6.17, \mathrm{p}<0.004)$ reflected stronger, although still non-significant, macrophyte type influences at MCN $(F=7.88, \mathrm{p}<0.068)$ and MCE $(F=7.36, \mathrm{p}<0.074)$ compared to MUD $(F=2.94, \mathrm{p}<$

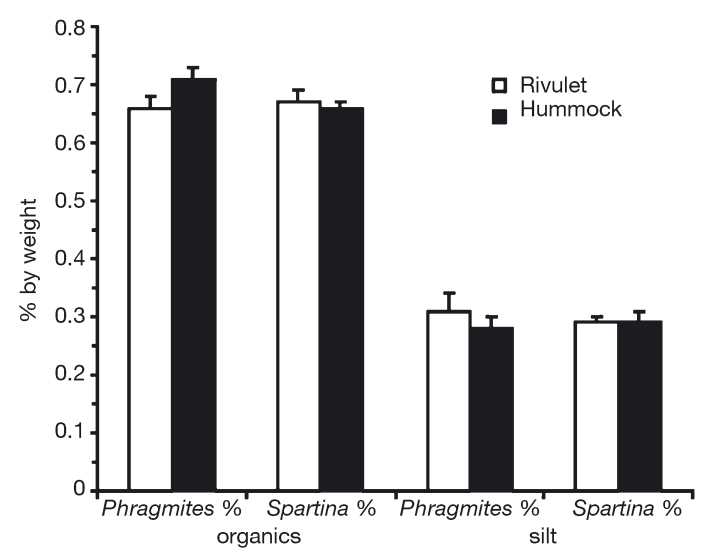

Fig. 3. Phragmites australis and Spartina alterniflora marshes. Percent organic and percent silt fraction for sediments collected from rivulet and hummock areas (averaged over all sites). Bars indicate mean percent (+1 SE) 


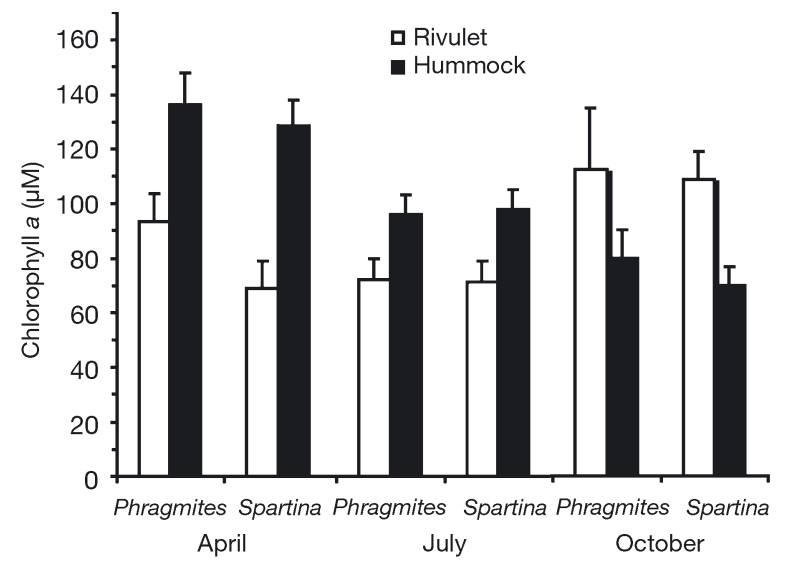

Fig. 4. Phragmites australis and Spartina alterniflora marshes. Chlorophyll a concentrations in rivulet and hummock areas for April, July and October sampling. Bars indicate means (+SE). Concentrations do not differ among macrophyte type but differ between rivulet and hummock areas for all sampling periods

$0.19)$ and $\operatorname{MCS}(F=1.68, \mathrm{p}<0.29)$. For both $\mathrm{MCN}$ and MCE, higher percent organics occurred in Phragmites marshes.

Benthic chlorophyll a concentrations differed between rivulet versus hummock subsites for all sampling periods (April, July, October) in both macrophyte types (Fig. 4, April: $F=28.13$, p < 0.0001; July: $F=9.98$, $\mathrm{p}<0.0043$; October: $F=5.72, \mathrm{p}<0.022-$ MUD and MCN sites only). Chlorophyll a concentrations were higher in hummock subsites during April and July, but patterns were reversed in October. No other significant main effects nor any significant interactive effects were detected.

\section{Benthic macro-infaunal patterns}

The benthic macro-infaunal community at the 4 paired marsh sites was numerically dominated by a typical mesohaline assemblage, including the polychaetes Capitella capitata, Hobsonia florida and Laeonereis culveri, oligochaetes, insect larvae (especially Chironomus spp.), clam (Cyrenoidea sp.) and the gastropod Hydrobia minuta (Tables 1 \& 2). During summer, strong interactions were apparent only for the gastropod $H$. minuta, between topography and macrophyte type (Table 1). $H$. minuta was more common in Spartina than in Phragmites marshes (Fig. 5), with strongest effects observed in rivulet habitats because of low occurrence of this snail on the hummocks (Fig. 6). The only other taxa to show significant differences among macrophyte type was the amphipod Gammarus mucronatus, which was also more common in Spartina marshes. Although differences in abundance for most individual taxa among macrophyte types were not significant, due to high variability in numbers, most taxa had higher overall mean numbers in Spartina versus Phragmites marshes. Friedman's test indicated a significant overall community trend towards higher rank abundance of fauna in Spartina versus Phragmites marshes (10 of 12 species more common in Spartina: Fig. 5). This test compared rank abundance for all species in Phragmites versus Spartina marshes to determine if there were a consistent overall pattern in rank abundance for all species considered together.

While there were few differences among macrophyte types for individual taxa, several taxa exhibited differences in abundance related to small-scale topography. Chirodotea (isopod), Gammarus mucronatus (amphipod), Leptochelia dubia (tanaid), and Acarina (mites) were all more common in hummock than in rivulet microhabitats (Fig. 6). Hobsonia florida (polychaete), Hydrobia minuta (gastropod), and Laeonereis (polychaete) were more common in rivulet areas than in hummock microhabitats. Few differences were observed between high and low tidal areas, but amongsite effects were strong for both Chirodotea and Cyrenoidea (bivalve); higher abundances of both species occurred at MUD and MCN sites than at MCE and MCS. Relative abundance between Phragmites and Spartina marshes for both species was consistent across all sites.

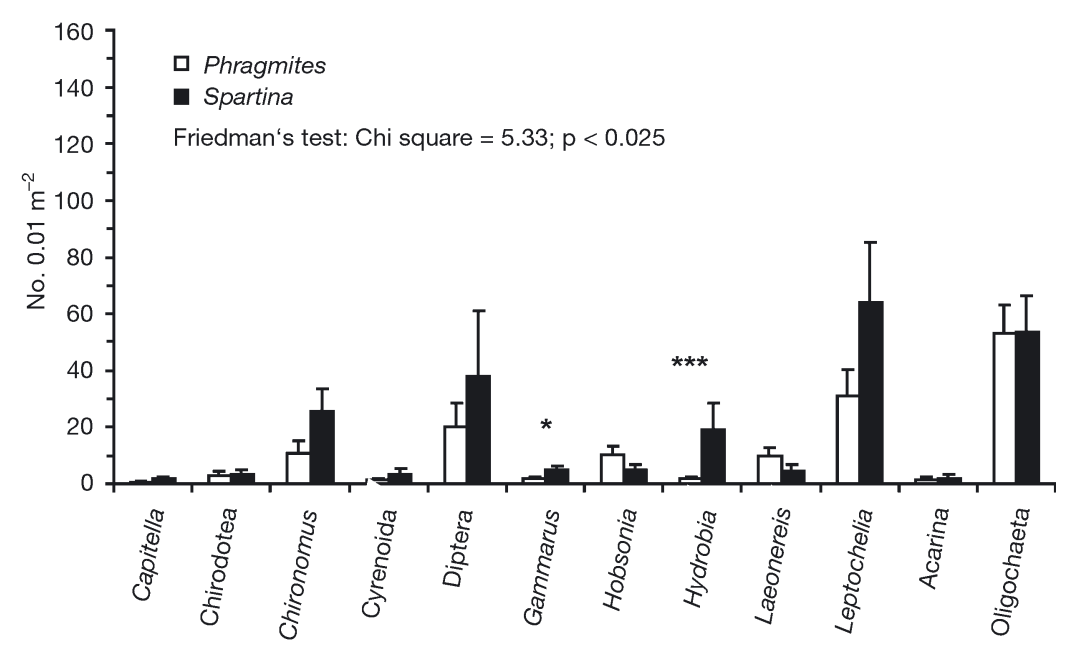

Fig. 5. Phragmites australis and Spartina alterniflora marshes. Mean faunal densities $(n=32,+\mathrm{SE})$ in July. Significant differences between macrophyte type are indicated above pairs of bars $(* p<0.05, * * * p<0.001)$. Friedman's test results are for rank abundance patterns of all species combined, indicating general whole-community trend for greater rank abundance in Spartina. Full specific names as in Table 1 


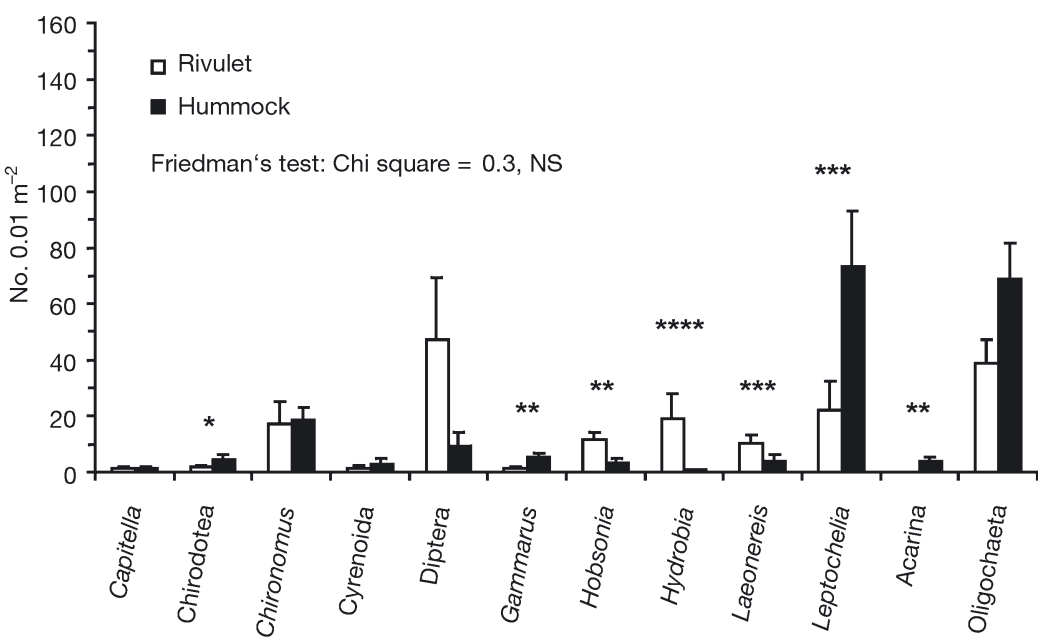

Fig. 6. Phragmites australis and Spartina alterniflora marshes. Mean faunal densities $(\mathrm{n}=32,+\mathrm{SE})$ for rivulet and hummock habitats in July. Significant differences between rivulet and hummock habitats are indicated above pairs of bars $\left({ }^{*} \mathrm{p}<0.05,{ }^{* *} \mathrm{p}<0.01,{ }^{* * *} \mathrm{p}<0.001,{ }^{* * * *} \mathrm{p}<0.0001\right)$. Friedman's test results are for rank abundance patterns of all species combined

Principal components analysis for summer samples revealed 2 major patterns (Fig. 7). The first was dominated by rivulet versus hummock effects, with similar topographies clustering together. The second pattern represented overall site differences, whereby pairs of Phragmites and Spartina marshes at the MCE and MCS sites tended to separate from those at the MUD and MCN sites. The MCS and MCE sites are both located in the upper part of Marshy Creek (Fig. 1), so the site patterns may reflect estuarine location effects. However, these divisions were weak, with the first 2 components representing only $49.8 \%$ of the total variance.

We detected no strong interactions in fall samples (Table 2). Only Hydrobia minuta showed significant differences in abundance among macrophyte types; it was more common in Spartina than in Phragmites marshes (Fig. 8). Unlike summer, during the fall we did not detect a significant trend towards higher rank abundance in Spartina marshes, with only 7 of 12 taxa having higher mean abundance in Spartina. The reduced influence of macrophyte-type effects appeared to be related to greater densities (although not significantly so) of several taxa within Phragmites stands during fall than in summer (Figs. 5 \& 8). Fewer sites in the fall analyses may also have contributed to a decreased ability to detect small-magnitude differences among macrophyte types. An analysis of the summer data, considering only MUD and MCN sites (the sites sampled in fall) indicated higher rank abundance for most fauna in Spartina; however, the trend was not significant $\left(\chi^{2}=1.33\right)$. In the fall, 7 taxa exhibited significant differences among topographic features (Fig. 9). Chirodotea, Cyrenoidea, Gammarus mucronatus, Leptochelia dubia and Acarina were more common in hummock than in rivulet habitats (4 of these taxa also showed the same pattern for summer samples). Diptera larvae (excluding Chironomus spp.) and Hydrobia minuta were more common in rivulet than in hummock microhabitats. As with summer samples, elevation was not associated with strong variations in abundance, and there was little difference in overall abundance between the 2 sites sampled in the fall.

\section{DISCUSSION}

Plant-type effects were detectable in this study, but were not strong relative to topographic effects. For the sediment and chlorophyll a measurements, only percent

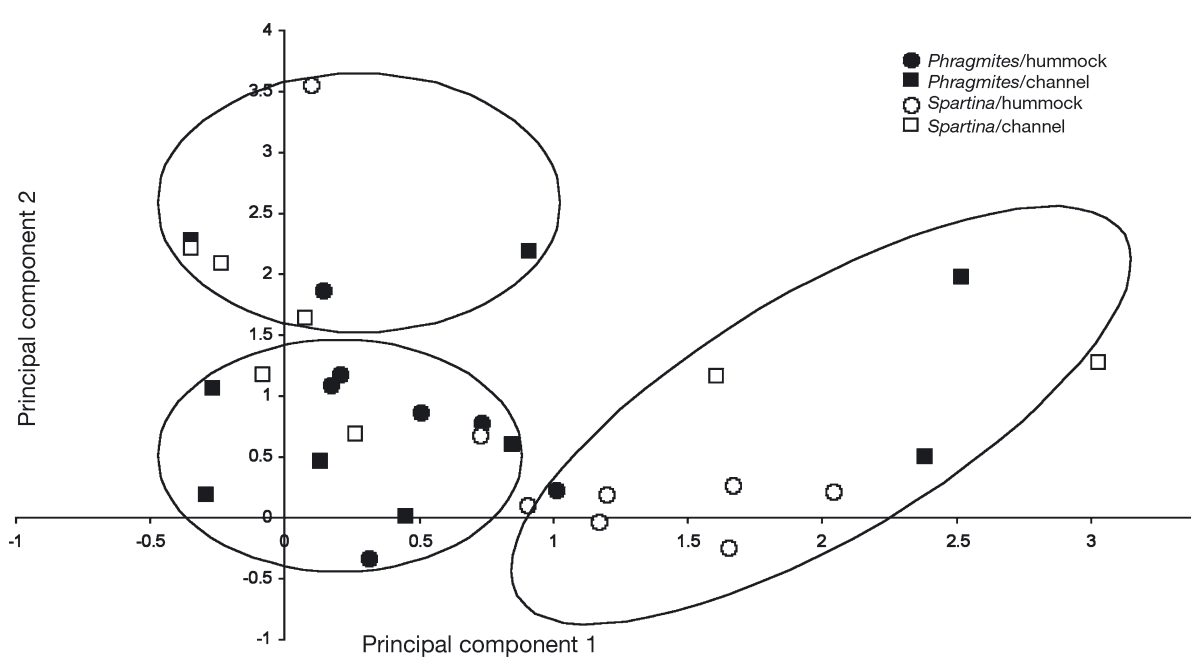

Fig. 7. Phragmites australis and Spartina alterniflora marshes. Biplot of first 2 principal components for samples separated by species composition. The sample characteristics (macrophyte type and habitat type) indicated by different symbols and groupings were determined by cluster analysis. First component was dominated by habitat type (hummock vs rivulet topography), second component was dominated by site (gradient from MCE/MCS to $\mathrm{MUD} / \mathrm{MCN}$ ) 


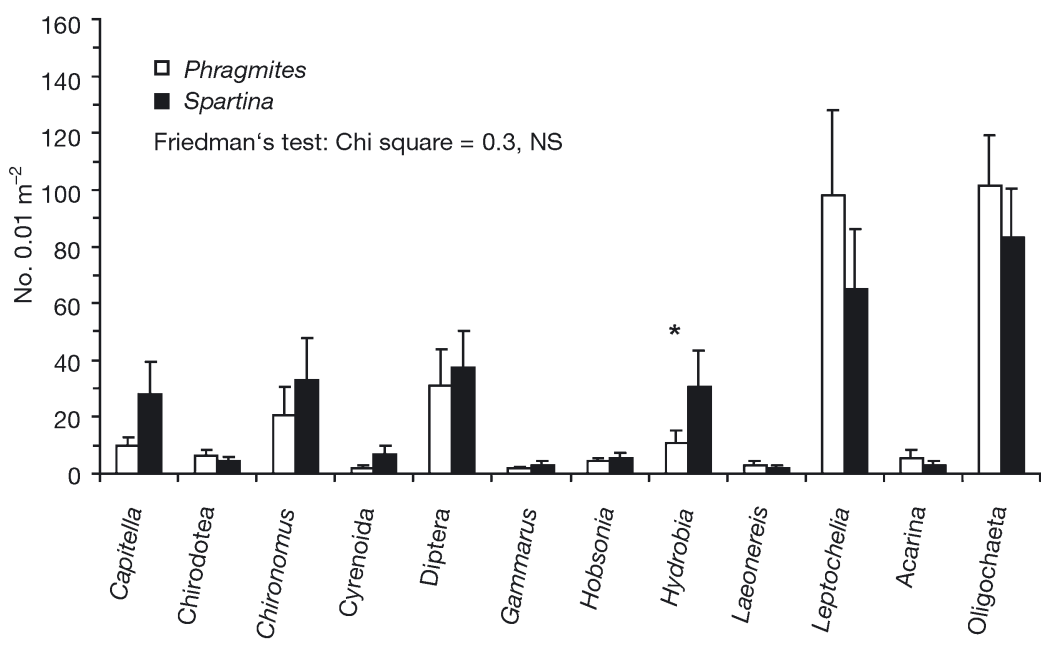

Fig. 8. Phragmites australis and Spartina alterniflora marshes. Mean faunal densities $(\mathrm{n}=16,+\mathrm{SE})$ in October. Significant differences between macrophyte type indicated above pair of bars $(* p<0.05)$. Friedman's test results are for rank abundance patterns of all species combined

organics displayed a difference among sites, and this only in hummock microhabitats. Among individual macro-infaunal species, only the snail Hydrobia minuta (both seasons) and Gammarus mucronatus (summer only) showed significant macrophtye-type effects, both being more common in Spartina than in Phragmites stands. H. minuta has previously been found to be uncommon/absent in marshes recently invaded by Phragmites (Talley \& Levin 2001). Rank tests also indicated a significant trend towards lower rank mean abundance of species in Phragmites than in Spartina marshes. The results of our study are consistent with others that have found small detectable effects or mixed effects of Phragmites invasion on macroinfaunal abundances. In comparisons of macrofauna between Phragmites and Spartina marshes, Warren et al. (2001) found no direct effect of Phragmites, but rather found a correlation with litter that might itself vary with plant type (Windham \& Lathrop 1999). Weis \& Weis (2000) found little behavioral affinity differences of Uca pugnax between Phragmites versus Spartina in laboratory arenas, although nektonic fishes and decapods displayed some differences. Fell et al. (1998) did not find evidence of differences in macrofaunal prey resources for mummichogs between Phragmites and Spartina marshes. Talley \& Levin (2001) observed shifts in faunal abundance patterns, with several burrowing taxa having reduced abundance and several surfacefeeding forms having greater abundances in Phragmites-invaded areas than in adjacent non-invaded areas. These shifts were accompanied by shifts in organic matter and plant biomass. Indirect effects on macrofauna may relate to differential predator abundances among macrophyte types (Able \& Hagan 2000), but Meyer et al. (2001) found no significant differences in nekton between Phragmites and Spartina marshes at our study locations.

There has been considerable concern about potential community changes associated with the spread of Phragmites (Havens et al. 1997, Chambers et al. 1999, Rice et al. 2000, Weis \& Weis 2000, Talley \& Levin 2001). While differences were detectable between paired Spartina and Phragmites marshes in this study, these differences were not strong, as measured by absolute differences in the mean abundance of species between these plant types as well as the number of taxa exhibiting significant density effects. Although greater replication might have revealed more significant patterns, the influence of macrophyte type was less than that of general site location or microhabitat. A question raised by this and other studies (Fell et al. 1998, Weinstein \& Balletto 1999, Able \& Hagan 2000, Able et al. 2001, Meyer et al. 2001, Talley \& Levin 2001, Warren et al. 2001) is whether such differences represent significant ecological changes. While there were few differences observed in this study for individual taxa, there is evidence for cumulative community differences between Phragmites- and Spartinadominated marshes in mesohaline Chesapeake Bay.

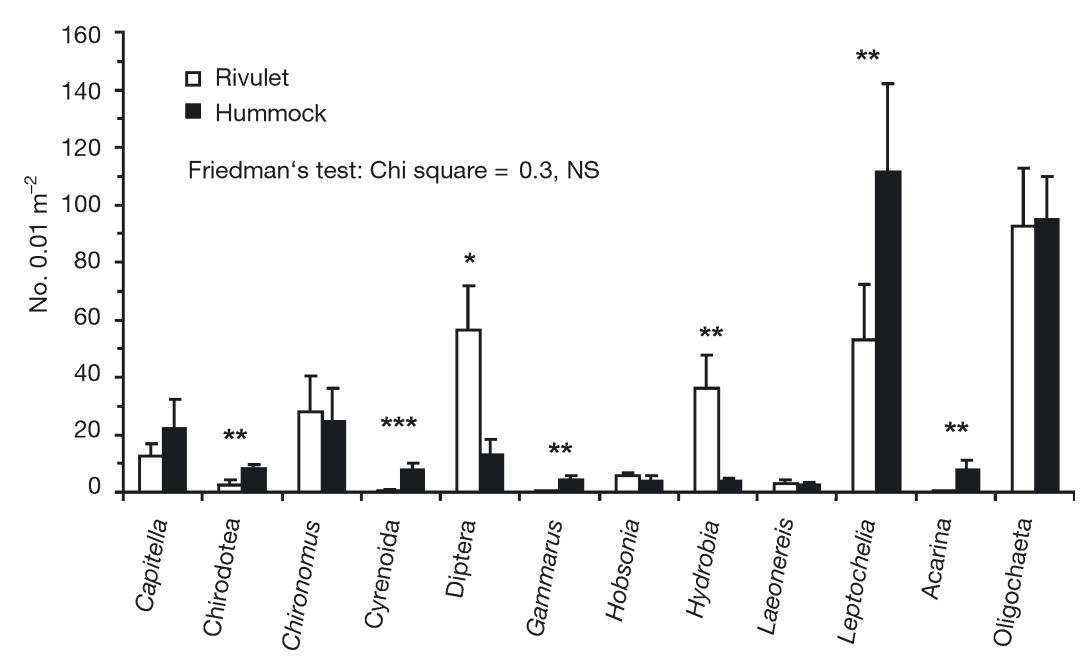

Fig. 9. Phragmites australis and Spartina alterniflora marshes. Mean faunal densities $(n=16,+$ SE) for rivulet and hummock habitats in October. Significant differences between rivulet and hummock habitats are indicated above pairs of bars $(* \mathrm{p}<0.05, * * \mathrm{p}<0.01, * * * \mathrm{p}<0.001)$. Friedman's test results are for rank abundance patterns of all species combined 
In contrast to macrophyte-type effects, small-scale topography had strong effects on macro-infaunal abundance even over the scale of centimeters sampled in this study: 7 of 12 species showed differences between rivulet and hummock areas in summer and 7 taxa also exhibited differences among these habitats in fall (9 taxa overall). Surface-dwelling crustaceans (Chirodotea, Gammarus mucronatus, Leptochelia dubia), mites and juvenile bivalves (Cyrenoidea) were more abundant in hummock than in rivulet areas, whereas polychaetes (Hobsonia florida, Laeonereis culveri), a surface feeding snail (Hydrobia minuta), and insect larvae were more numerous in rivulet than hummock areas. Benthic chlorophyll a also differed among rivulet and hummock areas, although the pattern changed temporally. Among the major differences between rivulets and hummocks are that hummocks are vegetated, several centimeters higher in elevation, and have root material present, whereas rivulets are unvegetated, lower, and have no root material but some detrital material. Although tidal location can clearly influence marsh macro-invertebrate abundance and species composition (e.g. LaSalle \& Bishop 1987, Lin 1999), we did not detect a strong influence of tidal height/distance into the marsh on macrofaunal densities over the ranges examined here, as evidenced by high- versus low-marsh comparisons. Whaley \& Minello (2002) suggested that factors affecting predator access, such as distance into a marsh for their Gulf of Mexico marshes, may have greater affects on infaunal abundances over small elevational gradients. Our results suggest that local affects of vegetation presence may be more responsible for the observed differences in faunal abundance patterns. Even on local scales (centimeters), the presence of vegetation may affect immediate sediment deposition and current patterns (Leonard et al. 2002), detrital and sediment organic levels, accessibility to predators (predation pressure), and physical structure. The crustaceans that were more abundant on hummocks have epibenthic foraging habits and may be responding to local structure (reduced predator accessibility), the presence of benthic microalgal food resources near plant stems, and detrital deposits (though there was no significant difference in percent organics between rivulets and hummocks in this study). Small-scale sampling and experimental manipulations of structure would be necessary to determine mechanisms of response.

The results of our study comparing macrophyte influence on benthic macrofauna document the importance of small-scale topographic features in controlling macrofaunal distributions. Topographic features (rivulet vs hummock) on the scale of centimeters common in many marsh systems, along with broad site-location differences, had a greater influence on faunal abun- dances than macrophyte type. Such small-scale features are often overlooked, or at least not explicitly discussed, in comparisons of marsh systems. These small-scale features may have important influences, and variations in the frequency with which they are sampled among marshes may lead to spurious differences between sites. While topography was similar among marsh types sampled in our study, it may vary between marshes or with dominant macrophyte type. Such features need to be stratified in sampling designs comparing functional attributes of marshes.

Acknowledgements. The authors acknowledge help from A. Crosby, J. Hartsell and D. Wells. This project was funded from grants by the NOAA/NMFS Restoration Center and NMFS, EFH Program.

\section{LITERATURE CITED}

Able KW, Hagan SM (2000) Effects of common reed (Phragmites australis) invasion on marsh surface macrofauna: response of fishes and decapod crustaceans. Estuaries 23: 633-646

Able KW, Nemerson DM, Bush R, Light P (2001) Spatial variation in Delaware Bay (USA) marsh creek fish assemblages. Estuaries 24:441-452

Benoit LK, Askins RA (1999) Impact of the spread of Phragmites on the distribution of birds in Connecticut marshes. Wetlands 19:194-208

Blossey B (2002) Replacement of native North American Phragmites australis by introduced invasive genotypes. Bot Electronic News 284:1-4

Boesch DF, Turner RE (1984) Dependence of fishery species on salt marshes: the role of food and refuge. Estuaries 7 : 460-468

Chambers RM, Meyerson LA, Saltonstall K (1999) Expansion of Phragmites australis into wetlands of North America. Aquat Bot 64:261-273

De'ath G (1999) Principal curves: a new technique for indirect and direct gradient analysis. Ecology 80:2237-2253

Fell PE, Weissbach SP, Jones DA, Fallon MA and 5 others (1998) Does invasion of oligohaline tidal marshes by reed grass, Phragmites australis (Cav.) Trin. Ex Steud, affect the availability of prey resources for the mummichog, Fundulus heteroclitus L.? J Exp Mar Biol Ecol 222:59-77

Havens KJ, Priest WI III, Berquist H (1997) Investigation and long-term monitoring of Phragmites australis within Virginia's constructed wetland sites. Environ Manag 21: 599-605

Hettler WF Jr (1989) Nekton use of regularly-flooded saltmarsh cordgrass habitat in North America, USA. Mar Ecol Prog Ser 56:111-118

Holland AF, Shaughnessy AT, Hiegel MH (1987) Long-term variation in mesohaline Chesapeake Bay macrobenthos: spatial and temporal patterns. Estuaries 10:227-245

Kneib RT (1984) Patterns of utilization of intertidal salt marsh by larvae and juveniles of Fundulus heteroclitus (Linaeus) and Fundulus luciae (Baird). J Exp Mar Biol Ecol 83:41-51

Kneib RT (1988) Testing the indirect effects of predation in an intertidal soft-bottom community. Ecology 69:1795-1805 Kneib RT, Stiven AE (1978) Growth, reproduction, and feed- 
ing of Fundulus heteroclitus (L.) in a North American salt marsh. J Exp Mar Biol Ecol 31:121-140

LaSalle MW, Bishop, TD (1987) Seasonal abundance of aquatic diptera in two oligohaline tidal marshes in Mississippi. Estuaries 10:303-315

Leonard LA, Wren PA, Beavers RL (2002) Flow dynamics and sedimentation in Spartina alterniflora and Phragmites australis marshes of the Chesapeake Bay. Wetlands 22: 415-424

Levinton JS (1982) Marine biology. Prentice-Hall, Englewood Cliffs, NJ

Lin J (1999) Influence of location in a salt marsh on survivorship of ribbed mussels. Mar Ecol Prog Ser 156:105-110

Lorenzen C (1967) Determination of chlorophyll and pheopigments: spectrophotometric equations. Limnol Oceanogr 12:343-346

McIvor CC, Odum WE (1988) Food, predation risk, and microhabitat selection in a marsh fish assemblage. Ecology 69: 1341-1351

Meyer DL, Johnson JM, Gill JW (2001) Comparison of nekton use of Phragmites australis and Spartina alterniflora marshes in the Chesapeake Bay, USA. Mar Ecol Prog Ser 209:71-84

Meyerson LA, Saltonstall K, Windham L, Kiviat E, Findlay S (2000) A comparison of Phragmites australis in freshwater and brackish marsh environments in North America. Wetlands Ecol Manag 8:89-103

Miltner RJ, Ross SW, Posey MH (1995) Influence of food and predation on the depth distribution of the juvenile spot (Leiostomus xanthurus) in tidal marshes. Can J Fish Aquat Sci 52:971-982

Minello TJ, Zimmerman RJ (1992) Utilization of natural and transplanted Texas salt marshes by fish and decapod crustaceans. Mar Ecol Prog Ser 90:273-285

Minello TJ, Zimmerman RJ, Medina R (1994) The importance of edge for natant macrofauna in a created salt marsh. Wetlands 14:184-198

Peterson GW, Turner RE (1994) The value of salt marsh edge vs interior as a habitat for fish and decapod crustaceans in a Louisiana tidal marsh. Estuaries 17:235-262

Pinckney J, Zingmark RG (1993) Biomass and production of benthic microalgal communities in estuarine habitats. Estuaries 16:887-897

Posey MH, Ambrose WG Jr (1994) Effects of proximity to an offshore hard-bottom reef on infaunal abundances. Mar Biol 118:745-753

Posey MH, Alphin TD, Powell CM (1997) Plant and infaunal communities associated with a created marsh. Estuaries 20:42-47

Posey MH, Alphin TD, Cahoon LB, Lindquist DG, Mallin MA, Nevers MB (2002) Top-down versus bottom-up limitation in benthic infaunal communities: direct and indirect effects. Estuaries 25:999-1014

Rice D, Rooth J, Stevenson JC (2000) Colonization and expan-

Editorial responsibility: Otto Kinne (Editor),

Oldendorf/Luhe, Germany sion of Phragmites australis in upper Chesapeake Bay tidal marshes. Wetlands 20:280-299

Rooth JE, Stevenson JC (2000) Sediment deposition patterns in Phragmites australis communities: implications for coastal areas threatened by rising sea level. Wetlands Ecol Manag 8:173-183

Royce CF (1970) An introduction to sediment analyses. Arizona State University, Tucson, AZ

Rozas LP, Zimmerman RJ (2000) Small-scale patterns of nekton use among marsh and adjacent shallow unvegetated areas of the Galveston Bay estuary, Texas. Mar Ecol Prog Ser 193:217-239

SAS Institute (1990) SAS procedures guide, version 6. SAS Institute, Cary, NC

Sokal RR, Rohlf FJ (1981) Biometry: the principles and practice of statistics in biological research, 2nd edn. WH Freeman, New York

Talley TS, Levin LA (1999) Macrofaunal succession and community structure in Salicornia marshes of southern California. Estuar Coast Shelf Sci 49:713-731

Talley TS, Levin LA (2001) Modification of sediments and macrofauna by an invasive marsh plant. Biol Invasions 3: $51-68$

Warren RS, Fell PE (1995) Tidal wetland ecology of Long Island Sound. In: Dreyer GD, Niering WA (eds) Tidal marshes of Long Island Sound: ecology, history and restoration. Connecticut College Arboretum, New London, p 22-41

Warren RS, Fell PE, Grimsby JL, Buck EL, Rilling GC, Fertik RA (2001) Rates, patterns, and impacts of Phragmites australis expansion and effects of experimental Phragmites control on vegetation, macroinvertebrates, and fish within tidelands of the lower Connecticut River. Estuaries 24: 90-107

Weinstein MP, Balletto JH (1999) Does the common reed, Phragmites australis, affect essential fish habitat? Estuaries 22:793-802

Weis JS, Weis P (2000) Behavioral responses and interactions of estuarine animals with an invasive plant: a laboratory analysis. Biological Invasions 2:305-314

Whaley SD, Minello TJ (2002) The distribution of benthic infauna of a Texas salt marsh in relation to the marsh edge. Wetlands 22:753-766

Windham L (2001) Comparison of biomass production and decomposition between Phragmites australis (common reed) and Spartina patens (salt hay grass) in brackish tidal marshes of New Jersey, USA. Wetlands 21:179-188

Windham L, Lathrop RG Jr (1999) Effects of Phragmites australis (common reed) invasion on aboveground biomass and soil properties in brackish tidal marsh of the Mullica River, New Jersey. Estuaries 22:927-935

Zimmerman RJ, Minello TJ (1984) Densities of Panaeus aztecus, $P$. setiferus and other natant macrofauna in a Texas salt marsh. Estuaries 7:421-433

Submitted: February 5, 2003; Accepted: May 13, 2003

Proofs received from author(s): September 12, 2003 